\title{
PETROLEUM PROFIT TAX VOLATILITY AND ECONOMIC GROWTH IN NIGERIA
}

\author{
Ojutawo, I. R ., Adegbie, F. F ${ }^{2}$., \& Salawu, R. $\mathbf{O}^{3}$. \\ Department of Accounting, \\ School of Management Sciences, \\ Babcock University, Ilishan-Remo, \\ Ogun State, Nigeria \\ Corresponding Author's emails: ojutawo@yahoo.com
}

\begin{abstract}
Nigeria has experienced downward slope in its productivity and economic growth. This affects the macroeconomic environment as it is evident that the country has challenges in fixing their roads, challenging in achieving national plan, high rate of unemployment, low quality education and low standards of living. In all these, studies have implicated low and unsteady revenue generation in the country. This study investigated petroleum profit tax volatility on economic growth in Nigeria, using inflation and exchange rates as moderating variables. This study adopted ex post facto research design. Data were obtained from certified sources; namely, National Bureau of Statistics, Central Bank of Nigeria Statistical Bulletin and Federal Inland Revenue Services for the 1981Q1-2017Q4, amounting to one hundred and eight (108) observations. Data were exposed to the scrutiny of the appropriate regulatory agencies for validity and reliability. Pre-estimation tests were conducted using Pearson correlation and stationarity tests. The post-estimation tests included linearity, Heteroskedasticity, Breusch-Godfrey serial Correlation Lagrangian Multiplier and stability test. Data were analyzed using both descriptive and inferential statistics. Findings revealed that Petroleum profit tax volatility had positive and significant effect on EG in Nigeria $\left(R^{2}=0.56, \beta_{1}=0.422, t_{(107)}=6.927, p<0.05\right)$. This study concluded that Petroleum profit tax volatility affects economic growth in Nigeria. It was recommended that government should formulate tax policies that will encourage steady tax revenue. In addition, government should ensure prudent application of tax fund to the development of infrastructure that would translate into economic growth
\end{abstract}

KEYWORDS: economic growth, gross domestic products, tax evasion, petroleum profit tax volatility, petroleum profit tax, tax revenue, tax volatility

\section{INTRODUCTION}

Most of the research work from advanced countries noted that volatility resulted from tax rate changes, increase in tax base and economic conditions (Seegert, 2012). Most of these factors could not be tested directly due to paucity of data and the level of monetization of the economy (Ajide, 2014). The argument is that advanced economy level of revenue volatility and series is caused by economic factors, tax rate and tax base while a holistic view of emerging economies locating the sub-Sahara Africa, expressed that maintaining economic conditions does not move in the direction of institutional authorities either due to the level of monetization of the economy and saboteurs impounding the region. For tax base in 
developing economy there is little aggression to expand tax tentacles to cover new areas within the region. Inland revenue services in most of their exercises recycle on old transactions and contacts to generate revenues for the government projects. At this approach, the country witness evasions of which some are extreme on the economy. Economic issues, other variables such as corruption, regulatory policies and inspector's auditor, corrupt nation, offer of bribe, to circumvent policies and procedures of government revenue.

In tax business, whenever government puts pressures on the tax collectors for additional revenue drive, tax inspectors and auditors are hired for compliance. Tax payers in turn hire auditors to prepare their books, negotiate and render returns. On the part of government, hired personnel will be paid, which will impact negatively on the collection. On the part of the tax payers, negotiations will be directed towards savings in tax payment to accommodate the bills of the hired auditors. For a country that is noted for corrupt practices, transparency International, it is suspicious that tax collections will suffer evasions and clear under payment.

In the drives, we observed price hike in crude oil as well as pump prices of premium spirit that contributed over $80 \%$ of the nation's revenue at either sides of the divide (Abiola \& Asiweh, 2012). The constant experience of volatile revenue does not support planning and incremental government budget in Nigeria. Most of the government forecast would be affected as it occurred in years 2018 to 2020 (Adegbie, Jayeoba \& Kwarbai, 2016). Government took to borrowing with high repayment costs to meet the demand for services within the domestic economy. In a country where corruption index is very high, regulatory compliance is challenged and citizens prefer to weigh options of fine/penalties and their personal gains to evade tax, it becomes eminent that tax revenue volatility becomes the order of the day.

Over time, countries all over the world believe in rating themselves in terms of strengths, ranging from military might, intellectual contributions, technical dispositions, financial capability and levels of development. This brought in the idea of developed nations and developing nations in the country of nations. For a country to have favourable business positions, it is perceived that its level of economic growth must be sustainable and favourably comparable with other nations by putting into measure their gross domestic product as well as their per capita income.

Haller (2012) posited that economic growth of any nation is a function of an efficient use of the available resources by increasing the capacity of production of a country. It causes redistribution of economies between population and society. It is easier to redistribute the income in a dynamic growing society than in a static one. When the rate of economic growth is high the price of goods and services rises and consequently, unemployment rate shows decreases in the number of job opportunities as well as the standard of living of the people. Siyanbola, Adedeji, Adegbie, and Rahman (2017) also mentioned that price increase generates inflation, unemployment and other consequences on the Nigeria nation.

According to Rodrik (2008) the central lesson from the past 50 years of development research and policy is that, economic growth is the most effective way to pull people out of poverty 
and deliver on their wider objectives for a better life. One of the most fundamental economic issues that have received extensive attention in the economic literature to date centres on economic growth as mentioned by the Department for International Development (DFID 2016) which looked into the causes of economic growth, as a measurement parameter, and asked the questions of how and why do countries grow faster than the other? What are the causes of disproportionate rates of growth across countries? The DFID wants to note the specific factors causing differential growth rates in countries. Attempts at answering these questions have spawned an avalanche of reasons as factors, ranging from tax incentive for industrial growth development as proposed by Adegbie, Jayeoba, and Kwabai (2016) economic, social, cultural, political and more recently, institutional reasons have been included. De Haan, Lundström, and Sturm (2006), as reported in the work of Ajide (2014), mentioned that Heritage Foundation defined Economic Freedom as the absence of government coercion or constraint on the production, distribution, or consumption of goods and services beyond the extent necessary for citizens to protect and maintain liberty itself.

Kira (2013) posited that Gross Domestic Product (GDP) is the determinant of a country's economic growth. It is the primary indicator used to measure the healthiness of a country's economy. It is also used to determine the standard of living of individuals in an economy. Onuoha, Ibe, Njoku, and Onuoha (2015), in embracing the definition of GDP, said it is the market value of all officially recognised final goods and services produced within a country in a given period of time. Kira (2013) stated that Gross Domestic Product takes into account the market value of each good or service rather than adding up the quantities of the goods and services directly. Gross Domestic Product is important in an economy because it is used to determine if an economy is growing more quickly or more slowly (Ojong, Anthony, \& Arikpo, 2016; Okafor, 2012; Okauru, 2011; Okauru, 2012; Okezie, 2012; Okoh, Onykwelu, \& Iyidiobi, 2016; Okoli, Njoku, \& Kaka, 2014; Okonjo, 2013; Okoye \& Raymond, 2014; Okwara \& Amori, 2017; Okwori \& Sule, 2016). In addition, it is used to compare the size of economies throughout the world. Again, the Gross Domestic Product is used in the comparison of relative growth rate of economies throughout the world. For instance, the Federal Reserves in the United States uses it as one of the indicators of whether the economy needs to be restrained or stimulated (Onuoha et al, 2015).

Nigeria has experienced a serious decline of revenue due to the decreasing oil price and production challenges. Hence, Nigeria must enhance its taxation to ensure stable flow of revenue for financing development (Musa, Saad and Ibrahim, 2017; Adegbie, Jayeoba and Kwabai, 2016). Taxes and tax system are essential in nation building. They are required for state capacity building for meaningful economic development (Bautigam, Fjeldstad and Moore, 2005). The fundamental goal of any revenue authority is to collect taxes and duties payable according to the law (Oladipupo \& Obazee, 2016).

According to the works of Geetanjali and Venugopal (2018); Adaramola and Ayeni (2015), economic growth is a complex, long-run phenomenon, subjected to constraints like: excessive rise of population, limited resources, inadequate infrastructure, inefficient utilisation of resources, excessive governmental intervention, institutional and cultural models that make the increase difficult. Economic growth is obtained by an efficient use of the available resources and by increasing the capacity of production of a country. It facilitates 
the redistribution of incomes between population and society. The cumulative effects, the small differences of the increase rates, become big for periods of one decade or more. It is easier to redistribute the income in a dynamic, growing society, than in a static one. Haller (2012) posits that there are situations when economic growth is confounded with economic fluctuations. The application of tax policies could lead to the elimination of recessionary gaps and to increasing the GDP beyond its potential level.

The suspicion is that Economic performance is measured by economic growth as agreed in economic literature. Revenues from taxes, sales of crude oil, royalties, properties, land use are nation's economic resource. In the past few years, revenue from crude oil are fast tinning out and government plan is being challenged. The implication of this is the declining economic growth as learnt from the school of economics. Tax as a component of government revenue could be viewed as an area of focus for generating revenue that will tackle the declining revenue and government expenditure gap (Abomaye-Nimennibo, Chika and Eyo 2018). The effect is further challenged on provision of basic amenities for the country as well as medical (high rate of infant mortality), infrastructures, low levels of living, and low level of literacy. Tax as at today constitutes between $80 \%$ to $95 \%$ of the nation's revenue (Abiola and Asweh, 2012), hence, it should be investigated whether leakages in tax revenue by actions of trends in revenue, tax base, economic conditions, political factors, tax penalties, tax compliance costs, tax bribe create volatility for different tax revenues and adversely affecting economic growth of Nigeria.

For government to realize potential sums, the level of tax compliance must be high Krauskopf \& Prinz (2011). The shifts in this direction will cause volatility of the revenue Kumaraswamy \& Quamar (2019). Mahangila (2017) the impact of Tax Compliance Costs on Tax Compliance Behaviour. Llacer, Miguel, Noguera \& Tapia, (2013). The research of Maina (2017) on the the Effect of Consumption Taxes on Poverty and Income Inequality in Kenya was aimed at using government tax revenue to allievate poverty (Manhire, 2015). The works of (Oboh \& Adedeji, 2012; Olaseyitan \& Sankay, 2011) equally posited that tax revenue leakages affect Economic Growth in Nigeria.

Olopade \& Olopade (2010) remarked that government expenditure impacts on economic growth as well as development in developing countries with a case study from Nigeria business environment. In bid to realize more fund for government, Olugbenga \& AyeniAgbaje (2015) believed that tax structure will equally yielded positive impact on economic Growth in Nigeria. Omolehinwa and Naiyeju (2015) understood the essence of government revenue aligned for accuracy in accounting for government revenue in Nigeria. In the same vein, (Onakoya \& Afintinni, 2016; Onaolapo, Fasina \& Adegbite, 2013; Onuoha, Ibe, Njoku \& Onuoha, 2015; Oloidi \& Oluwalana, 2014) stated that taxation supports the business of government by impacting on economic growth in Nigeria.

The study of Anojan and Nimalathasan (2018) looked into the mean difference between budgeted total revenue, expenditure and actual total revenue and expenditure of Sri Lanka from 2005 to 2017. A follow up on budget trend in the country depicts the pictures of increasing yearly revenue, which has been falling continuously below the budgeted yearly expenditures of the government. A review of the nation's budget from 2015 to the request of 2019 as depicted below highlights annual deficits. These are funding gaps that need to be 
filled; otherwise low level of living, low income, life expectancy and mortality rate could be in the increase especially as Nigeria witnesses an increase in population. These are basically economic growth problems in addition to inefficient use of resources as well as misallocation of the scarce resources.

In this study, interest is keen at obtaining research explanations between petroleum profit tax revenue volatility and economic growth in Nigeria. The objective of the study was to ascertain the impact of petroleum profit tax volatility on economic growth in Nigeria by testing the hypothesis that there is no significant impact of petroleum profit tax volatility on economic growth in Nigeria. This could help expose and resolve the gap between government spending and revenue that becomes yearly issue.

\section{LITERATURE REVIEW}

\section{Petroleum Profit Tax (PPT)}

Adeyemi (2015), in his work on Petroleum Profits Tax Act in Nigeria, stated that the principal legislation applicable to petroleum operation in Nigeria is the Petroleum Profits Tax Act (PPTA) which became operative on the 1st of January, 1958. Ilaboya \& Ofiafor (2014) agree that although the act was dated 23rd April 1959, the Act has retroactive effect from 1st January 1958. Since then, the PPTA has been amended by several pieces of legislation, which have now been consolidated into the current PPTA (1990) and has also since 1990 been subjected to several. David -West (2013) assert that PPT is levied on the income of companies engaged in upstream petroleum operation. The rate is $85 \%$ for Joint Ventures and $50 \%$ for Production Sharing Contracts (PSC).

Okoh, Onyekwelu and Iyidiobi, (2016) stated that Nwezeaku in 2005 affirms that PPT involves the charging of tax on the income accruing from petroleum operations. He notes that the importance of petroleum to the Nigeria economy gave rise to the enactment of different laws regulating taxation of incomes from petroleum operations. Petroleum profit tax is a tax applicable to upstream operations in the oil industry as it is related to rent, royalties, margin, oil mining prospecting and exploration leases. It is the most important tax in Nigeria in terms of its share of total revenue, contributing over $70 \%$ of government revenue and $95 \%$ of foreign exchange earnings (Odusola, 2006). Okpe (2003) explains that petroleum profit is levied on the current year basis. That is to say, the basis period for petroleum profit tax (PPT) is the actual profit of the accounting period. Put in another way, the basis period for any assessment year is the same as the accounting period of the company.

Ekeocha, Ekeocha, Malaolu and Oduh (2012), supported that petroleum Profit Tax is subject to any resident company or person in charge of a non-resident company who are exploring for petroleum or producing it. This also includes any liquidator, receiver, or agent of liquidator or receiver of any company carrying on petroleum operations in Nigeria.

Payment Information on the Petroleum Profit Tax is a type of pre-paid tax. An organisation has to prepare and submit its annual tax return to Federal Inland Service, within five months of the end of each assessment year. The payment is done mainly in two segments of 12-13 phases. The first segment is the estimated annual return paid not later than February of each 
year. The tax due is then paid, in 12 Months instalments throughout the year. In case the accumulated actual tax exceeds the tax paid a 13th Month payment can be paid. If the opposite occurs, the company will get the refund.

In the words of Buba (2007), Nigerian law by virtue of the Petroleum Profits Tax Act 1990 requires all companies engaged in the extraction and transportation of petroleum' to pay tax. Adegbie (2011) further stated that the taxable income of a petroleum company comprises proceeds from the sale of oil and related substances used by the company in its own refineries plus any other income of the company incidental to and arising from its petroleum operations. Adereti (2011) explained that the taxable income of a petroleum company is subject to tax at $85 \%$, but this percentage is lowered to $65.75 \%$ during the first 5 years of operation but where oil companies operate under production sharing contracts they will be liable to tax at a rate of $50 \%$.

This makes the foreign trade sector the major source of revenue in the 1960s. Some structural changes emerged in the revenue profile in the early 1970s whereby indirect taxes gave way to direct taxes with the emergence of the oil boom (Egwakhide, 1988). The fall in non-oil tax revenue due to the neglect of the traditional (agricultural) sources was matched by an increase in import duties until 1973. Further, there was an appreciable increase in revenue from excise duties in the 1970s due to the enhanced performance of the industrial sector (Buba 2007).

This overall picture has been sustained up till now given the dominant role of the oil sector as a major source of government revenue. This scenario appears to conform to Musgrave's (1969) theory to the effect that as an economy develops, more reliance may be placed on direct tax revenue. Some caution is advisable in confirming the relevance of Musgrave's theory to the Nigerian environment.

The study of Ogbonna and Ebimobowei (2012) on the impact of petroleum revenue on the economy of Nigeria for the period 1970 to 2009 shows that a strong correlation exists between petroleum revenue and GDP. They concluded that oil based revenue if invested efficiently in the economy will, to a large extent, make material difference on GDP. From the result, it could be deduced that PPT has a positive impact on Nigeria's economy but it will be good to further investigate the roles other taxes play on the economy's GDP both individually and as a lump sum which is one of the objectives this study aims to achieve.

\section{Petroleum Profit Tax and economic growth in Nigeria}

Onaolapo, Fasina, and Adegbite (2013) studied empirically the effect of petroleum profit tax (PPT) on Nigeria economy, secondary data were obtained from the Central Bank of Nigeria statistical bulletin covering the period of 1970 to 2010. In concluding the analysis, multiple regressions were employed to analyse data on such variables Gross Domestic Product (GDP), petroleum profit tax, inflation, and exchange rate were all found to have significant effects on the Economics Growth.

Ihenyen and Mieseigha (2014) examined taxation as an instrument of economic growth in Nigeria. Using annual time series data sourced from the Central Bank of Nigeria (CBN) Statistical Bulletin during the period 1980 through 2013, data of Corporate Income Tax 
(CIT), Value Added Tax (VAT) and Economic Growth (GDP) was estimated using the Ordinary Least Square (OLS) technique. The empirical result suggests that the hypothesized link among corporate income tax, value added tax and economic growth indeed exist in the Nigerian context. Thus, the result offered tantalizing evidence that taxation is an instrument of economic growth in Nigeria. This conclusion points to the need for additional measures by government in ensuring that taxpayers do not avoid and evade tax so that income can be properly redistributed in the economy.

Ogbonna and Ebimobowei (2012) studied the effects of petroleum income on the Nigerian economy for the period 2000 to 2009 using the gross domestic product (GDP), per capita income (PCI), and inflation (INF) as the explained variables, and oil revenue, petroleum profit tax/royalties (PPT $\backslash R$ ), and licensing fees (LF) as the explanatory variables. The sample covers all the economic sectors of the country, including the oil sector and the non-oil sector. The study relied mostly on secondary data from Central Bank of Nigeria's Statistical Bulletin, Nigerian National Bureau of Statistics, and the Nigerian National Petroleum Corporation. Simple regressions models and Statistical Package for Social Sciences were used in this study to evaluate the data collected. The results show that oil revenue has a positive and significant relationship with GDP and PCI, but a positive and insignificant relationship with INF. Similarly, PPT/R has a positive and significant relationship with GDP and PCI, but a negative and insignificant relationship with inflation. It was also found that LF has a positive but insignificant relationship between GDP, PCI and INF, respectively. Based on these findings, this study concludes that petroleum income (oil revenue and PPT/R) has positively and significantly impacted the Nigerian economy when measured by GDP and PCI for the period 2000 to 2009. This study, therefore, suggests that the effect of petroleum income on the Nigerian economy was positive for the period reviewed.

Saheed, Abarshi and Ejide (2014) examined the empirical relationship between Economic growth and petroleum taxation. In an attempt to investigate the effect of petroleum taxation on economic growth, a simultaneous equation model was used to establish a relationship between the variables Domestic Consumption and production of crude oil, petroleum taxation and government policies. The result obtained from the analysis revealed that a strong positive relationship exists between domestic consumption, Petroleum profit tax (PPT), government policy and economic growth (GDP).

Additionally, Success, Success and Ifurueze (2012) examined the impact of Petroleum Profit Tax on the economic development of Nigeria for the period 2000-2010. The method of analysis used was ordinary least square method. Results showed that Petroleum profit tax impact positively on Gross Domestic Product of Nigeria and it is statistically significant.

Furthermore, Okafor (2012) explored the impact of income tax revenue on the economic growth of Nigeria as proxied by the gross domestic product (GDP) using the ordinary least square (OLS) regression analysis over the period 1981-2007. The regression result indicated positive and significant relationship. However, actual tax revenue generated in most years fell below the level expected. The anomaly was attributed to dysfunctional ties in the income tax system, loopholes in tax laws and inefficient tax administration. 
Theoretical framework was built on the Benefit Theory. The benefit approach was initially developed by Knut Wicksell in 1896 and Erik Lindahl in 1919, two economists of the Stockholm School. The benefit principle is a concept in the theory of taxation as addressed in public finance. It explains the basic taxes to pay for public-goods expenditures on a politically-revealed willingness to pay for benefits received. The principle is sometimes likened to the function of prices in allocating private goods (Fritz \& Charles; 2013) in its use for assessing the efficiency of taxes and appraising fiscal policy of nations.

The circumstances that led to the theory can be seen in the brief biography of the theorists. Johan Gustaf Knut Wicksell was born on December 20th, 1851 and died on May 3rd, 1926. His father's considerable estate allowed him to enroll at the University of Uppsala in 1869 to study mathematics and physics. He received his first degree in two years, and he engaged in graduate studies until 1885, when he received his doctorate in mathematics. In 1887, Wicksell received a scholarship to study on the Continent, where he heard lectures by the economist Carl Menger in Vienna. In the following years, his interests began to shift toward the social sciences, particularly economics.

As a lecturer at Uppsala, Wicksell attracted attention because of his opinions about labour. His fiery ideas had attracted some attention, but his first work in economics, Value, Capital and Rent in 1892, went largely unnoticed. In 1896, he published studies in the theory of Public Finance and applied the ideas of marginalism to progressive taxation, public goods and other aspects of public policy, attracting considerably more interest. He was married to Anna Bugge in 1887. Erik Lindahl was born on 21st, November 1891 and died on 6th January, 1960. He was a Swedish economist and a professor of economics at Uppsala University between (1942 and 1958) and in 1956-1959, he was the President of the International Economic Association. He was an advisor to the Swedish government and the central bank. Lindahl posed the question of financing public goods in accordance with individual benefits. The quantity of the public good satisfies the requirement that the aggregate marginal benefit equals the marginal cost of providing the good. "Lindahl was probably the most theoretically rigorous member of the Stockholm School; Erik Lindahl was the only member of that group who stayed wholly within academia. Although he obtained his degree at Lund and was highly influenced by Knut Wicksell, he was not Wicksell's student.

A Lindahl tax is a form of taxation conceived by Erik Lindahl in which individuals pay for public goods according to their marginal benefits. In other words, they pay according to the amount of satisfaction or utility they derive from the consumption of an additional unit of the public good. Onakoya and Afintinni (2016) explain that it can be seen as an individual's share of the collective tax burden of an economy. The optimal level of a public good is that quantity at which the willingness to pay for one more unit of the good, taken in totality for all the individuals is equal to the marginal cost of supplying that good. Lindahl tax is the optimal quantity times the willingness to pay for one more unit of that good at this quantity. Erik Lindahl was deeply influenced in this by Knut Wicksell and proposed a method for financing public goods in order to show that consensus politics is possible (Charles, Ekwe \& Azubike, 2018). As people are different in nature, their preferences are different, and consensus requires each individual to pay a somewhat different tax for every service, or good that he consumes. If each person's tax price is set equal to the marginal benefits received at the ideal 
service level, each person is made better off by provision of the public good and may accordingly, agree to have that service level provided.

The importance of the benefit principle to taxation and economic growth is that it takes a market-oriented approach to taxation. The objective is to accurately determine the optimal amount of revenue that should be spent on public goods. More equitable/fair because taxpayers, like consumers, would "pay for what they get". Taxes are more akin to prices that people would pay for government services. Consumer sovereignty - specific rather than general charges are more direct so the preferences of taxpayers, rather than government planners, are given more weight. In an efficient allocation of limited resources, it is less likely that funds will be overinvested in low priority programmes. There is no free lunch; tax payers would have a better understanding of the costs of public goods. The concept provides the foundation for voluntary exchange theory. It has also been applied to such subjects as tax progressivity, corporation taxes, and taxes on property or wealth (Musgrave \& Musgrave; 1973).

Concluding this part, this theory maintains that justice in taxation is secured by taxing each citizen in the proportion to the benefits he derives from the activity of state (Ibanichuka et al. 2016). It is also known as insurance theory or quid pro quo theory of taxation. It implies that taxes should be paid by those people who receive the direct benefit of government programmes and projects out of the taxes paid. However, it has some objections, the weak and poorer people receive great benefits from the government in the form of free education etc. Though they receive the greatest benefit, they are, however, least able to bear the burden of taxation.

Empirically, we reviewed the works of Onaolapo, Fasina, and Adegbite (2013) on the effect of petroleum profit tax (PPT) on Nigeria economy, secondary data were obtained from the Central Bank of Nigeria statistical bulletin covering the period of 1970 to 2010. In concluding the analysis, multiple regressions were employed to analyse data on such variables Gross Domestic Product (GDP), petroleum profit tax, inflation, and exchange rate were all found to have significant effects on the Economics Growth.

Ihenyen and Mieseigha (2014) examined taxation as an instrument of economic growth in Nigeria. Using annual time series data sourced from the Central Bank of Nigeria (CBN) Statistical Bulletin during the period 1980 through 2013, data of Corporate Income Tax (CIT), Value Added Tax (VAT) and Economic Growth (GDP) was estimated using the Ordinary Least Square (OLS) technique. The empirical result suggests that the hypothesized link among corporate income tax, value added tax and economic growth indeed exist in the Nigerian context. Thus, the result offered tantalizing evidence that taxation is an instrument of economic growth in Nigeria. This conclusion points to the need for additional measures by government in ensuring that taxpayers do not avoid and evade tax so that income can be properly redistributed in the economy.

Ogbonna and Ebimobowei (2012) studied the effects of petroleum income on the Nigerian economy for the period 2000 to 2009 using the gross domestic product (GDP), per capita income (PCI), and inflation (INF) as the explained variables, and oil revenue, petroleum 
profit tax/royalties (PPT $\backslash R$ ), and licensing fees (LF) as the explanatory variables. The sample covers all the economic sectors of the country, including the oil sector and the non-oil sector. The study relied mostly on secondary data from Central Bank of Nigeria's Statistical Bulletin, Nigerian National Bureau of Statistics, and the Nigerian National Petroleum Corporation. Simple regressions models and Statistical Package for Social Sciences were used in this study to evaluate the data collected. The results show that oil revenue has a positive and significant relationship with GDP and PCI, but a positive and insignificant relationship with INF. Similarly, PPT/R has a positive and significant relationship with GDP and PCI, but a negative and insignificant relationship with inflation. It was also found that LF has a positive but insignificant relationship between GDP, PCI and INF, respectively. Based on these findings, this study concludes that petroleum income (oil revenue and PPT/R) has positively and significantly impacted the Nigerian economy when measured by GDP and PCI for the period 2000 to 2009. This study, therefore, suggests that the effect of petroleum income on the Nigerian economy was positive for the period reviewed.

Saheed, Abarshi and Ejide (2014) examined the empirical relationship between Economic growth and petroleum taxation. In an attempt to investigate the effect of petroleum taxation on economic growth, a simultaneous equation model was used to establish a relationship between the variables Domestic Consumption and production of crude oil, petroleum taxation and government policies. The result obtained from the analysis revealed that a strong positive relationship exists between domestic consumption, Petroleum profit tax (PPT), government policy and economic growth (GDP).

Additionally, success, success and Ifurueze (2012) examined the Impact of Petroleum Profit Tax on the economic development of Nigeria for the period 2000-2010. The method of analysis used was ordinary least square method. Results showed that Petroleum profit tax impact positively on Gross Domestic Product of Nigeria and it is statistically significant.

Furthermore, Okafor (2012) explored the impact of income tax revenue on the economic growth of Nigeria as proxied by the gross domestic product (GDP) using the ordinary least square (OLS) regression analysis over the period 1981-2007. The regression result indicated positive and significant relationship. However, actual tax revenue generated in most years fell below the level expected. The anomaly was attributed to dysfunctional ties in the income tax system, loopholes in tax laws and inefficient tax administration.

Justification for this study was made through the studies of Schaufele (2016) investigated Taxes, Volatility and Resources in Canadian Provinces. Fricke and Süssmuth (2013) conducted a study on Growth and volatility of tax revenues in Latin America. The works of Basdevant (2012) was conducted on Fiscal Policies and Rules in the Face of Revenue Volatility within Southern Africa Customs Union Countries, while the work of McNichol (2013) is on the Strategies to Address the State Tax Volatility Problem. Eliminating the State Income Tax Not a Solution was centred on budget and policy priorities. Balding and Dauchy (2013) investigated Federal Income Tax Revenue Volatility Since 1966. Talvi and Vegh (2005) studied Tax base variability and procyclical fiscal policy in developing countries. Garrett (2006) carried out evaluation on State Tax Revenue Variability: A Portfolio Approach. Abildgren (2005) estimated Danish general government budget balance and the 
cyclical budget volatility 1875-2003, Chong and Gradstein (2006) investigated policy volatility and growth, Kretzschmar, Moles and Constantinou (2005) investigated Taxation and volatility effects on real option models: a study of NorthSea oil fields. Seegert (2012) studied Optimal Taxation with Volatility A Theoretical and Empirical Decomposition Albrecht (2013) investigated Managing Tax Revenue Volatility. Sobel and Holcombe (1996) worked on measuring the Growth and Variability of Tax Bases over the Business Cycle. However, till date no study has linked tax revenue profile in terms of volatility and its implication for economic growth. Thus, this study fills a glaring hole in the literature.

\section{METHODOLOGY}

This study employed ex-post facto research design. This design was used in the work of to Adegbie, Jayeoba and Kwarbai (2016) to assess value added tax on growth and development of Nigeria. In the same vein, Lee and Gordon (2005) investigated Tax structure and economic growth, using cross-country data during 1970-1997. The ex-post facto research design was used because it involved the use of past records in order to determine the present association and to develop a predictive model of forecasting the future relationship that may exist between the variables (Akinyemi, 2016). More importantly, the needed data were sourced from the publications of the Central Bank of Nigeria (CBN) Statistical Bulletin, as well as the tax revenue profile of the Federal Inland Revenue Service (FIRS) and the National Bureau of Statistic (NBS). This study takes after the study of overton, Nukpezah and Ismayilov (2017), Balding and Dauchy, (2013), which made use of ex-post facto. In this study, both the descriptive and inferential statistics were adopted to achieve the stated objectives. This type of experimental design was also used by Kirchler, Muehlbacher and Hoelzl (2009).

The population of this study was Nigeria and it assessed the effect of tax revenue volatility on economic growth in Nigeria for the period 1981-2017. This is similar to the study of Chimilila (2017) in Tanzania where 192 months of times series data were employed for the study of variables. It should be noted that data for value added tax and education tax started from 1994 and 1996, respectively. This was the reason for both variables not starting in 1981 because their implementation starts at a later date. The total sample period is thirty-seven years, while for value added tax and education tax it was twenty-four and twenty-two years.

The data for this study was sourced mainly from the Central Bank of Nigeria (CBN) statistical bulletin, Federal Inland Revenue Service, National Bureau of Statistic and (NBS). The various versions of the Central Bank of Nigeria (CBN) Statistical Bulletin, the annual reports of the Federal Inland Revenue Service (FIRS) and National Bureau of Statistics (NBS) have been duly certified by regulatory agencies and were considered suitable and appropriate for public usage. 


\section{METHOD OF DATA ANALYSIS}

In accomplishing the objective of this study, the study employed both descriptive and inferential statistics. First, the study examined the descriptive properties of the data using the mean median, maximum, minimum, standard deviation. Second, it examined the time series properties of the variables, the Augmented Dickey Fuller (ADF) and the Phillip and Perron (PP) unit root tests were equally used. Third, it tested for the long run relationship between tax revenue volatility and economic growth in Nigeria, the Autoregressive Distributed Lag (ARDL) model for cointegration was used in addition to test for short run model, the error correction model was equally used. For the model to adjust back to equilibrium the error correction term is expected to be negative and statistically significant at 1,5 or 10 per cent level of significance. Finally, the post-estimation test was carried out to assess the probability of using the results for policy purposes. Here, the LM test was used to check if correlation exists in successive error terms. In addition, Ramsey RESET Test was used to examine if the estimated model is linearly and correctly specified. The Breusch-Pagan for heteroscedasticity tests was used to test if the variance of the error term is constant or not. The Jarque-Bera test was used to test if the specified model follows a normal distribution or not and finally, the cumulative sum of residual and cumulative sum of square residuals will be used to test the stability of the model.

\section{Model Specifications}

The Algebraic functional relations used to achieve this objective is stated as,

Y $\quad=\quad f(\mathrm{X})^{\mathrm{n}}$

Note that $Y=$ Dependent Variable proxy as Economic Growth (GDP)

$X=$ Independent Variable proxy as Petroleum Profit Tax Volatility (PPTV)

$\mathrm{GDP}=f(\mathrm{PPTV})$

The long-run relation of Petroleum Profit Tax Volatility and economic growth in Nigeria as stated in equation 1 is transformed into;

The long run relation of tax revenue volatility and economic growth in Nigeria is given in equation 3.3 as,

$$
\mathrm{LGDP}=\beta_{0}+\beta_{1} \mathrm{PPTV}+\varepsilon_{t}
$$

The scale variable measures Nigerian real GDP and PPTV is the Petroleum Profit Tax Volatility. The measure of Petroleum Profit Tax Volatility is constructed using the GARCH (generalized autoregressive conditional heteroskedasticity) approach. To distinguish the short-run effects of volatility measures from their long-run effects, Equation (3.4) is specified in an error-correction modelling form. Following Pesaran et al.'s (2001) bounds testing approach and rewrite (1) as follows: 
Model: Petroleum Profit Tax Volatility and Economic Growth

$$
\begin{aligned}
\Delta L n G D P=\alpha & +\sum_{i=1}^{n 1} \beta_{i} \Delta L n G D P_{t-1}+\sum_{i=0}^{n 2} \delta_{i} \Delta L n P P T V_{t-1}+\rho_{0} L n G D P_{t-1}+\rho_{1} L n P P T V_{t-1} \\
& +\varepsilon_{t}
\end{aligned}
$$

Where $\alpha$ is the intercepts from equations 3.4 and $\rho_{1}$ is the estimated coefficients for the explanatory variables, $\mathrm{t}$ represents the periods under study, $\varepsilon_{t}$ are the error term.

\section{ANALYSIS AND RESULTS}

This section presents the results of the analyses as depicted in model 3 with the dependent and independent variables. Obviously, the descriptive statistics are presented in Table 1, the relationship was determined through Pearson Product-Moment, the diagnostic test and the regression results herewith respectively. The results shed academic light on how income tax volatility may engineer economic growth

\section{Descriptive statistics}

Table 4.1 Descriptive Statistics

\begin{tabular}{lrrrrrrrrrr}
\hline Variables & Mean & Median & Max & Min & Std. Dev. & Skewness & Kurtosis & $\begin{array}{c}\text { Jarque- } \\
\text { Bera }\end{array}$ & Prob & Obs \\
\hline LGDP & 7.06 & 7.19 & 10.30 & 3.56 & 2.28 & -0.16 & 0.59 & 2.86 & 0.12 & 148 \\
LPPTV & 3.61 & 3.89 & 10.65 & -6.45 & 4.99 & -0.28 & 0.85 & 2.01 & 0.14 & 147
\end{tabular}

Notes: Table 4.1 shows the mean, median, maximum, minimum, standard deviation, skewness, kurtosis and Jarque-Bera test for normality of the variables. The dependent variable is log of gross domestic product (LGDP) the explanatory variable is logarithm of petroleum profit tax volatility (LPPTV) for the period 1981Q1-2017Q4 in Nigeria. The estimation process was facilitated using Eviews 10.

Source: Researcher's Computation 2019

\section{Interpretation of Descriptive Statistics}

Log of gross domestic product (LGDP): The mean value of the gross domestic product is 7.06 with a median of 7.19. In addition, it shows that the maximum value is 10.30 and the minimum value 3.56. This implies that the levels of economic growth in Nigeria differ across time period. It also shows that the total value of goods and services produced follows upward trends during the period of study. The standard deviation of 2.28 shows that the level of growth is susceptible to change in Nigeria. It also shows that economic growth in Nigeria follows a normal distribution because the Jarque-Bera test shows that the variable is normally distributed. Log of petroleum profit tax volatility (LPPTV): The mean value of the petroleum profit tax volatility is 3.61 with a median of 3.89. In addition, it shows that the maximum value is 10.65 and the minimum value -6.45 . This implies that the petroleum profit tax volatility in Nigeria differs across time period. The standard deviation of 4.99 shows that the petroleum profit tax volatility is susceptible to change in Nigeria. It also shows that 
European Journal of Accounting, Auditing and Finance Research

Vol.8, No.4, pp.38-61, April 2020

Published by ECRTD-UK

Print ISSN: 2053-4086(Print), Online ISSN: 2053-4094(Online)

petroleum profit tax volatility in Nigeria follows a normal distribution because the JarqueBera test of 2.01 shows that the variable is normally distributed.

\section{Pearson Correlation Result.}

Table 4.2 Correlation Matrix for Tax Revenue and Gross Domestic Product

\begin{tabular}{lrr}
\hline Variables & LGDP & LPPTV \\
\hline LGDP & 1.00 & \\
LPPTV & $\mathbf{0 . 9 0}$ & 1.00
\end{tabular}

Notes: Table 4.2 shows the Pearson pairwise correlation matrix. The dependent variable is log of gross domestic product (LGDP) the explanatory variable is logarithms of petroleum profit tax volatility (LPPTV) for the period 1981Q1-2017Q4 in Nigeria. The correlations are below the major diagonal and the bold coefficients denotes statistical significant at 1, 5 and 10 per cent. The estimation process was facilitated using Eviews 10.

Source: Researcher's Computation 2019.

This section discusses the degree of association between logarithms of petroleum profit tax volatility and with the log of gross domestic product (LGDP) for the period 1981Q1-2017Q4 in Nigeria. petroleum profit tax volatility with economic growth in Nigeria. The level of associations is in $90 \%$, respectively. The implication of these results is that increases in total petroleum profit tax volatility will lead to increases in economic growth in Nigeria. In sharp contrast, there is evidence that inflation has a negative insignificant relation with economic growth, this implies increases in inflation rate and will lead to decrease in economic growth.

\section{Result of the Stationary Test}

Stationary test is conducted to examine the time series properties of the variables over the study period. Specifically, the Augmented Dickey Fuller (ADF) and the Phillip-Perron unit root tests were used to test for stationary in the series and the result is presented in Table 4.3.

Table 4.3. Result of the Unit Root Test

\begin{tabular}{llcc}
\hline Variables & ADF & PP & Remarks \\
\hline LGDP & -1.470 & -0.900 & \\
$\Delta$ LGDP & $-3.779^{* * *}$ & $-5.000^{* * *}$ & $\mathrm{I}(1)$ \\
LPPTV & -1.634 & -1.629 & \\
$\Delta$ LPPTV & $-5.929^{* * *}$ & $-10.836^{* * *}$ & $\mathrm{I}(1)$
\end{tabular}

Notes: Table 4.3 presents the unit root test. The dependent variable is log of gross domestic product (LGDP) the explanatory variable is logarithm of petroleum profit tax volatility (LPPTV) for the period 1981Q1-2017Q4 in Nigeria. The correlations are below the major diagonal and the bold coefficients denotes statistical significant at 1,5 and 10 per cent. The estimation process was facilitated using Eviews 10. The critical value at 5 for intercept and trend is -3.50 and for intercept alone is -2.93 . $* *$ and $* * *$ indicates significant at 5 and 1 per cent respectively.

Source: Researcher's Computation, (2019). 
Stationary test is conducted to examine the time series properties of the variables over the study period. Specifically, the Augmented Dickey Fuller (ADF) and the Phillip-Perron unit root tests were used to test for stationary in the series and the result is show that the economic growth proxied with the gross domestic product, petroleum profit tax volatility, 3.779, 5.929, were stationary in their first differences, while company income tax volatility and value added tax volatility 6.105 and 3.321 were stationary at levels 5 per cent level of significance. It should be noted that because some of the different order of integration of the variables, the autoregressive distributed lag (ARDL) model approach to cointegration of Pesaran (2001), which allow for the combination of levels and first difference stationary variables were used.

\section{Regression analysis}

The prediction for this study is to assess the effect of petroleum profit tax volatility on economic growth in Nigeria for a period of 36 (1981-2017). This is weaved through regression analysis to estimate the interactions between variables.

Table 4.1 Full Information on the Effects of Petroleum Profit Tax Volatility on Economic Growth

Panel A: Long Run Estimates

\begin{tabular}{|c|c|c|c|c|}
\hline \multicolumn{5}{|c|}{ Dependent Variable: LGDP } \\
\hline Variable & Coefficient & S.E & t-stat & Prob \\
\hline LPPTV & 0.422 & 0.061 & 6.927 & 0.000 \\
\hline $\mathrm{C}$ & 7.352 & 1.051 & 6.997 & 0.000 \\
\hline
\end{tabular}

Panel B: Short -Run Estimates

\begin{tabular}{|c|c|c|c|c|}
\hline Variable & Coefficient & S.E & t-stat & Prob \\
\hline $\mathrm{D}($ LGDP(-1)) & 0.577 & 0.081 & 7.076 & 0.000 \\
\hline D(LPPTV(-2)) & 0.188 & 0.079 & 2.366 & 0.019 \\
\hline $\operatorname{ECM}(-1)$ & -0.006 & 0.002 & -3.878 & 0.000 \\
\hline Panel C: Diagnostic Tests & & Statistic & Prob. & \\
\hline Bound Test & & 4.942 & 0.050 & \\
\hline Serial Correlation & & 1.828 & 0.112 & \\
\hline Heteroscedasticity & & 1.963 & 0.144 & \\
\hline Linearity Test & & 1.770 & 0.114 & \\
\hline \multirow[t]{2}{*}{ R-square } & & 0.561 & & \\
\hline & & CUSUM & & \\
\hline Stability Test & & Stable & & \\
\hline
\end{tabular}

Notes: Table 4.5 reports the long-run estimates, short run estimates and the diagnostic tests for the relationship between petroleum profit tax volatility and economic growth. The dependent variable is the logarithm of gross domestic product and the logarithm of petroleum profit tax volatility represents the independent variable.: Source: Researcher's Computation 2019 
The long-run volatility models expressed in algebraic form is presented below:

$\mathrm{LGDP}=\beta_{0}+\beta_{1} \mathrm{PPTV}+\varepsilon_{\mathrm{t}}$

Substituting the value from the table above, the study obtained Model 2 estimates of long dynamics below.

Lgdp $=7.352+0.422 \mathrm{lpptv}$

$(6.997) * * *(6.927) * * *$

The asterisk signs that is ** and *** represent $5 \%$ and $1 \%$ level of significance.

In the short- run, the study obtained PPT Volatility Model thus.

$$
\begin{aligned}
& \Delta \mathrm{LGDP}=\alpha_{1} \Delta \mathrm{LGDP}(-1)+\alpha_{2} \Delta \mathrm{LPPTV}+\alpha_{3} \operatorname{ECM}(-1) \\
& \Delta \operatorname{lgdp}=0.577 \Delta \operatorname{lgdp}+0.188 \Delta \operatorname{lpptv}(-2)-0.006 \mathrm{ECM}(-1)
\end{aligned}
$$

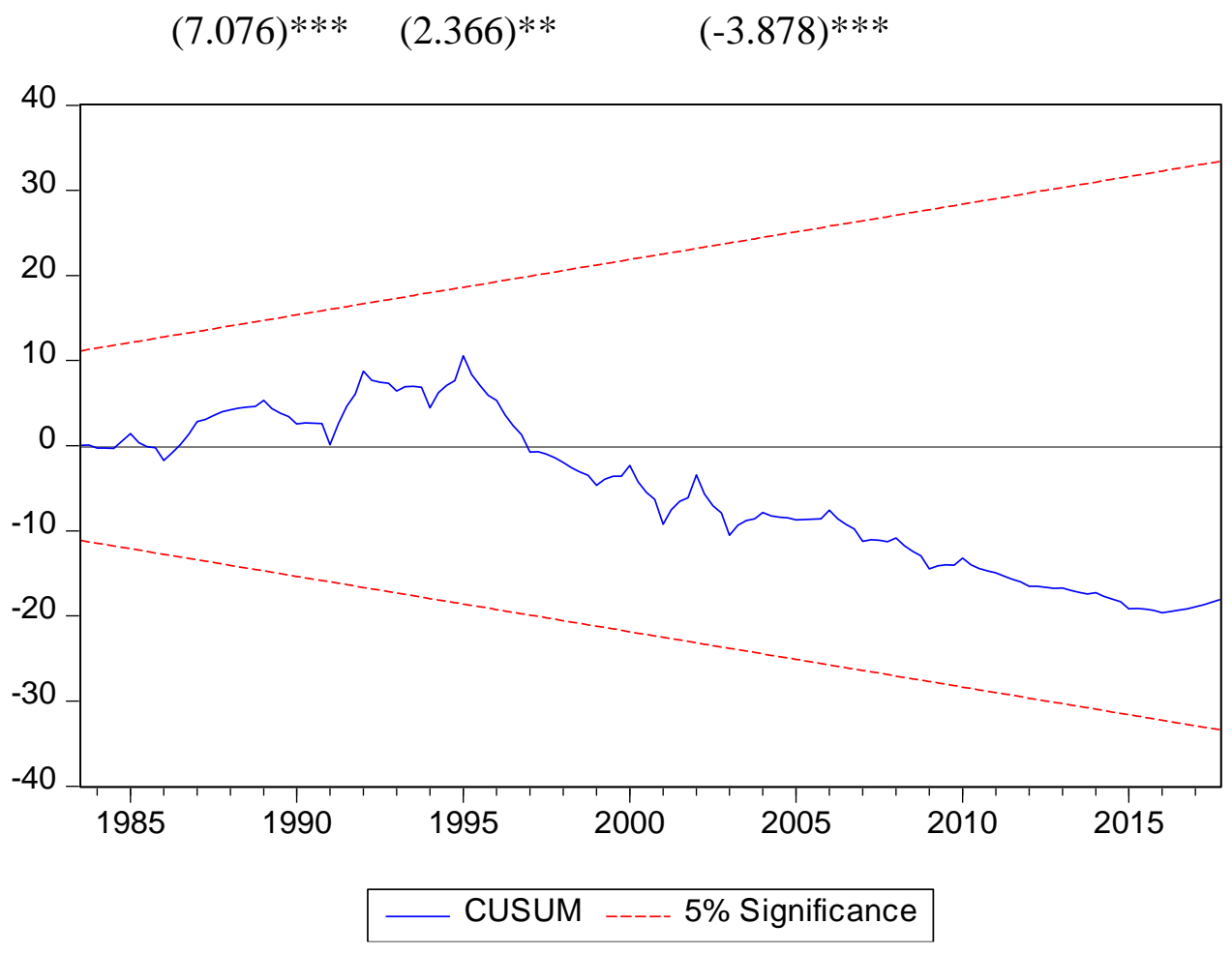




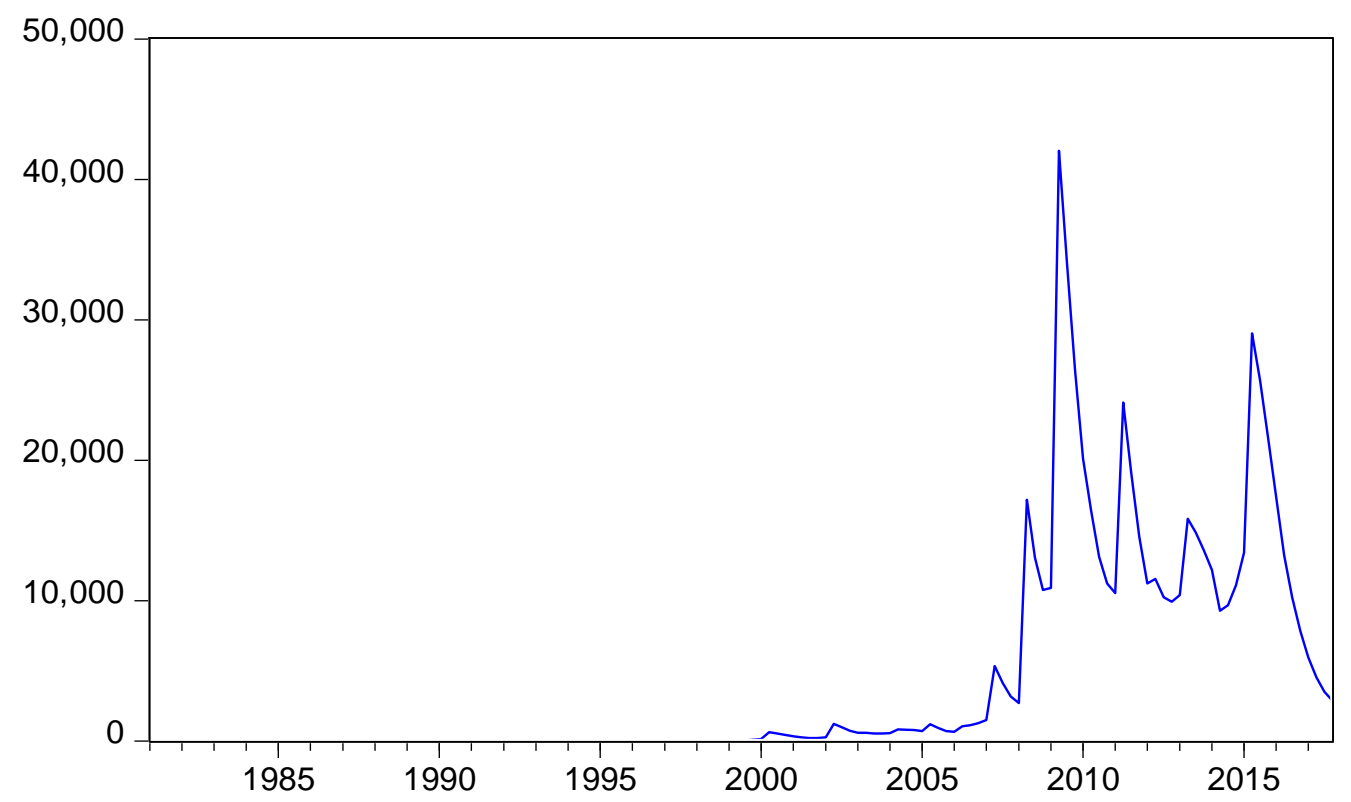

Fig. 1 Petroleum Profit Tax Volatility

\section{Interpretation}

The value of F-Stat is 4.942 and it is greater than the critical values bound at upper bound (I1) of 4.26, 3.5 and 3.13 at 1 percent (Appendix-Model II). This implies that the variables co-moved in the long run. Having found a long-run relationship between economic growth and petroleum profit tax volatility, the study then estimates the long-run and the short-run elasticities. The empirical results for the model, obtained through normalizing economic growth and petroleum profit tax volatility in the short and long run, are reported in Table 4.5.

The Long-Run Dynamics coefficients (elasticities) for the UECM model are given in the tables Panel A of Tables 4.5. In the long run, there is an evidence of a positive relationship between economic growth and petroleum profit tax volatility. This implies that increases in petroleum profit tax volatility will lead to increase in the economic growth in Nigeria. Furthermore, there is an evidence of a long-run significant relationship between economic growth and petroleum profit tax volatility in Nigeria $\left(\beta_{1}=0.422\right.$, t-test $\left.=6.927, \rho=0.000\right)$. This implies that petroleum profit tax volatility is a significant factor influencing changes in economic growth in Nigeria. Moreover, a 1 per cent increase in petroleum profit tax volatility will lead to $42.2 \%$ increase in economic growth in Nigeria in the long run. Thus, the null hypothesis that there is no significant effect of petroleum profit tax volatility on economic growth in Nigeria was rejected and the study accepts the alternative hypothesis that there is a significant relationship that exists between petroleum profit tax volatility and economic growth in Nigeria

The Short-run Dynamics is basically for two reasons. First, is to examine if changes and the statistical significance experienced in the long run also exist in the short run model. 
Second, is to examine the degree of adjustment back to equilibrium using the error correction term. The short-run adjustment process is measured by the error correction term $\mathrm{ECM}_{\mathrm{t}-1}$ and it shows how quickly variables adjust to a shock and return to equilibrium. For stability, the coefficient of $\mathrm{ECM}_{\mathrm{t}-1}$ should carry the negative sign and be statistically significant. The result shows that in the short-term petroleum profit tax volatility has a positive and significance relationship with the economic growth in the previous years $\left(\beta_{1}=0.577, \mathrm{t}\right.$-test $=7.076$, $\rho<0.000$ and $\beta_{2}=0.188$, t-test $\left.=2.366, \rho=0.019\right)$. In addition, the estimated coefficient for the $\mathrm{ECM}_{\mathrm{t}-1}$ reported in Panel $\mathrm{B}$ of 4.5 is negative and statistically significant $(\mathrm{ECM}=-0.006, \mathrm{t}-$ test $=-3.878, \mathrm{p}=0.000)$. This implies that deviations from economic growth equilibrium path are corrected by nearly 0.6 per cent over the following quarter. In other words, the adjustment process is slow for Nigeria. The statistical significance of the $\mathrm{ECM}_{\mathrm{t}-1}$ confirms the presence of long-run equilibrium relationship between economic growth and petroleum profit tax volatility in Nigeria. The R-square is 0.56 , this implies that petroleum profit tax volatility explains about $56 \%$ changes in economic growth. The balance of $44 \%$ is caused by factors outside this study.

\section{Diagnostic Test}

The linearity assumption of ARDL test was estimated using Ramsey Reset Test, F-statistics of 1.770 and its $\rho$-value is of 11.4 per cent is greater than 5 per cent chosen level of significance, thus the null hypothesis of linearity cannot be rejected. This implies that the model is correctly specified and that there is a linear relationship between the economic growth and petroleum profit tax volatility in Nigeria. Breusch-Pagan Test for Heteroskedasticity was conducted to test is the covariance of the estimated model error term is constant or not. The result suggests that a statistic of 1.963 is not statistically significant at 5 per cent level of significance, this implies that the null hypothesis of homoscedasticity could not be rejected, and thus, there is evidence that the covariance of the error terms have a constant finite variance.The Breusch-Godfrey Serial Correlation LM Test was carried out to determine if successive error terms are correlated. The probability value of F-statistic of 0.112 is in favour of the null hypothesis that there is no serial correlation in the residuals up to the specified lag order at 5 percent significant level. Thus, the study concluded that the successive error terms were not correlated in the estimated model for economic growth and petroleum profit tax volatility. Stability Test (CUSUM Residual Test).The CUSUM test for stability is meant to determine the appropriateness and the stability of the model. In addition, the CUSUM test is used to show whether the model is stable and is suitable for making long run decision. The CUSUM is also reported in Panel C. For Nigeria, the CUSUM test also shows that the estimated model is stable, this is because the plot of CUSUM statistic stays within a $5 \%$ significance level portrayed by two straight lines.

\section{CONCLUSION AND RECOMMENDATION}

In this era of globalisation, unfriendly tax policies may create room for capital flight from Nigeria to other countries with more relaxed tax policies. The move towards borderless world has opened up new opportunities for taxpayers to minimise their tax liabilities. Government should not only create an enabling environment for business establishment but also give all necessary support for its survival because profits of businesses are one of the major sources of tax revenue. 
There is a need for public private partnership in decision making process for good governance. Just like every other profit oriented businesses, the structure of tax administration should be customer oriented. Measures to assessing customer's satisfaction, employee's satisfaction and business oriented results should be put in place. In order to encourage voluntary compliance, tax policy formulation should be after due consultation with all the stakeholders. The gap between the citizens and the government is so wide that policies are made and forced down on the people without due consultation. For there to be a good tax administration, tax policies must be welcomed by all the citizens. Besides, the involvement of all stakeholders may further foster the sincerity of the government thereby reducing the problem of trust which had bedeviled tax administration.

The swings in the price of crude oil in recent years have contributed to high tax revenue volatility in the country. Tax revenue fluctuation is high in the area of crude oil as our economy is a mono cultural one, depending largely on proceeds from these resources. Tax volatility occurs on varying degrees among different components of taxes, throwing up unpredictable revenue that can confound government planners' effort on the budget preparation of the nation.

Volatility complicates the already difficult tasks of revenue forecasting and budgeting, but inherently, it is not bad. When receipts are higher than anticipated, government can improve on roads and bridges, pay down debts obligations, and equally build up reserves to face the future. In the same vein, if the surplus period is immediately followed by unanticipated low tax revenue, spending cut would be prompted, or tax increases to make ends meet. By studying volatility, policy makers can determine budgetary risk and put in place shockabsorbing strategies that could harness tax growth in good years to reduce the effect of lean years.

Food stocks could be enhanced by paying attention to agriculture in Nigeria to boast sustainable food production. Government infrastructure is required not only for agriculture but other areas of industries within the domestic economy to generate income to trigger more tax revenue.

Government should ensure strategies that will bridge the surplus and low tax collection periods by ensuring that a 'Raining Day Fund Account' is introduced to accommodate surplus revenue and put them in reserve for use at the scarce collection period. This fund should be dedicated to explicit and narrowly defined spending purposes. Government should reduce fiscal uncertainty by restricting spending from particular volatile tax streams. Excess fund from this stream should be deposited on a particular longer time savings account or sovereign wealth funds.

\section{Contribution to Knowledge}

To the best of the authors' knowledge, this is the first study to develop and test petroleum profit tax volatility in context of emerging economy. This study has thrown more light on volatile nature of tax revenue in Nigeria. In Nigeria this is one of the articles addressing the issue of volatility in Nigeria. It equally reveals the consequences on government budget at the levels of infrastructures, road network, education, and level of information technology. 
Volatility caused by economic changes affects government policy as well as welfare packages, provision of basic infrastructures, housing needs, schools and school enrolment, improvements on hospitals and attempts to reduce infant mortality by government.

\section{Reference}

Abildgren, K. (2005). Estimates of the Danish general government budget balance and the cyclical budget volatility 1875-2003 (No. 30). Danmarks Nationalbank Working Papers.

Abiola, J., \& Asiweh, M. (2012). Impact of tax administration on government revenue in a developing economy- a case study of Nigeria. International Journal of Business and Social Science, 3(8). 741-768.

Abomaye-Nimenibo, W. A. S., Eyo, M. J., \& Chika, F. H. (2018). An empirical analysis of tax revenue and economic growth in Nigeria from 1980 to 2015. Global journal of human social science research, 18(3), 8-40.

Adaramola, A. O. \& Ayeni-Agbaje, A. R. (2015). Tax Structure and Economic Growth in Nigeria: A Disaggregated Empirical Evidence (1986-2012). Research Journal of Finance and Accounting, 6(14), 20-32.

Adegbie, F. F. \& Fakile, A. S. (2011). Company Income Tax and Nigeria economic development. European Journal of Social Sciences, 22 (2), 309-320.

Adegbie, F. F., Jayeoba, O., \& Kwabai, J. D. (2016). Assessment of Value Added Tax on the Growth and Development of Nigeria Economy: Imperative for Reform. Accounting and Finance Research, 5(4), 2016.

Adereti, S. A, Sanni, M. R, \& Adesina, J. A (2011). Value Added Tax and Economic Growth

Adeyemi, B. A. (2015). The Fiscal Regime Governing Petroleum Profit Taxation in Nigeria. Available at SSRN 2703616.

Ajide, K. B. (2014). Determinants of economic growth in Nigeria. CBN Journal of Applied Statistics, 5(2), 147-170.

Akinyemi, S. (2016). Dropout in secondary schools in Lagos State: an analytical study of its Predictors. Journal of Research in Educational Management, 4(1), April 2016. Official Journal of Department of Educational Management, Lagos State University.

Albrecht, W.G. (2013). Managing Tax Revenue Volatility. The International Academy of Business and Public Administration Disciplines. The IABPAD Conference Proceedings. Orlando, Florida, January 2-5, 2013.

Anojan, V. \& Nimalathasan B., (2018) Comparative Study Between Budgeted and Actual Total Revenue, Total Expenditure of Sri Lanka, International Journal of Accounting and Financial Reporting, 8(3), 99-105.

Basdevant, O. (2012). Fiscal Policies and Rules in the Face of Revenue Volatility Within Southern Africa Customs Union Countries (SACU). WP/12/93, IMF Working paper.

Bautigam, D., Fjeldstad, O.H., \& Moore, M. (2005). Taxation and State-Building in Developing Countries: Capacity and Consent. Cambridge University Press, Cambridge, 30-33.

Buba, J. G. (2007). The Role of the Customs Reforms in Boosting Non-Oil Revenue in Nigeria. University of Jos, Nigeria Symposium 2007.

Charles, U. J., Ekwe, M. C., \& Azubike, J. U. B. (2018). Federally Collected Tax Revenue and Economic Growth of Nigeria: A Time Series Analysis. International Accounting 
European Journal of Accounting, Auditing and Finance Research

Vol.8, No.4, pp.38-61, April 2020

Published by $\boldsymbol{E C R T D}-\boldsymbol{U K}$

Print ISSN: 2053-4086(Print), Online ISSN: 2053-4094(Online)

and Taxation Research Group, Faculty of Management Sciences, University of Benin, Benin City, Nigeria.

Chimilila, C. (2017). "Forecasting tax revenue and its volatility in Tanzania", African Journal of Economic Review, 5(1).

Chong, A. \& Gradstein, M. (2006). Policy volatility and growth, Working Paper, No. 578, Inter-American Development Bank, Research Department, Washington, DC.

Dauchy, E. P., \& Balding, C. (2013). Federal income tax revenue volatility since 1966. Available at SSRN 2351376.

De Haan, J., Lundström, S., \& Sturm, J. E. (2006). Market-oriented institutions and policies and economic growth: A critical survey. Journal of Economic Surveys, 20(2), 157191.

DFID (2016). https://www.nao.org.uk/wp-content/uploads/2017/09/A-Short-Guide-to-theDepartment-for-International-Development.pdf

Egwakhide, F. O. (1988). Analysis of Structural Shifts of Government Revenue in Nigeria. The Nigerian Journal of Economic and Social Studies, 30(2).

Ekeocha, P. C., Ekeocha, C.S., Malaolu, V., Oduh, M. O. (2012) Revenue Implications of Nigeria's Tax System. Journal of Economics and Sustainable Development.3(8) 201206

Fricke, H. \& Süssmuth, B. (2013). Growth and volatility of tax revenues in Latin America, Working Paper, Universität Leipzig, Wirtschaftswissenschaftliche Fakultät, No. 124, Univ., Wirtschaftswissenschaftliche Fakultät, Leipzig.

Fritz, N., \& Charles, E. M. (2013). "Taxation," The Benefit Principle, Encyclopadia Britannica.

Garrett, T. A. (2006). Evaluating State tax revenue variability: a portfolio approach. Working papers 2006-008. Federal Reserve Bank of St. Louis.

Geetanjali, J., \& Venugopal, P. (2018). Impact of Direct Taxes on GDP: A Study. IOSR Journal of Business and Management (IOSR-JBM) e-ISSN: 2278-487X, p-ISSN: 2319-7668 PP 21-27. Name of Conference: International Conference on "Paradigm Shift in Taxation, Accounting, Finance and Insurance" 6 (2), 23-55.

Haller, A. P. (2012). Concepts of economic growth and development challenges of crisis and of knowledge. Economy Transdisciplinarity Cognition, 15(1), 66.

Ibanichuka, E. L., Akani, F. N., Ikebujo, \& Ogechi S. (2016). A Time Series Analysis of Effect of Tax Revenue on Economic Development of Nigeria. International Journal of Innovative Finance and Economics Research, 4(3), 16-23

Ihenyen, C. J., \& Mieseigha, E. G. (2014). Taxation as an instrument of economic growth (The Nigerian Perspective). Information and Knowledge Management, 4(12), 49 - 53.

Ilaboya, O. J., \& Ofiafor, E. (2014). Petroleum Profit Tax and Economic Growth in Nigeria. British Journal of Business and Management Research 1(2), 55-67,

Kira, A. R. (2013). The Factors Affecting Gross Domestic Product (GDP) in Developing Countries: The Case of Tanzania. European Journal of Business and Management $5(4), 20-56$

Krauskopf, T., \& Prinz, A. (2011). Methods to Reanalyze Tax Compliance Experiments: Monte Carlo Simulations and Decision Time Analysis. Public Finance Review, 39(1), 168-188. 
European Journal of Accounting, Auditing and Finance Research

Vol.8, No.4, pp.38-61, April 2020

Published by $\boldsymbol{E C R T D}-\boldsymbol{U K}$

Print ISSN: 2053-4086(Print), Online ISSN: 2053-4094(Online)

Kretzschmar, G. L., Moles, P. \& Constantinou, C. (2005). Taxation and volatility effects on real option models: a study of northsea oil fields. Centre for Financial Markets Research the Management School

Kumaraswamy, P. R., \& Quamar, M. M. (2019). The Shift. InIndia's Saudi Policy (pp. 129148). Palgrave Macmillan, Singapore.

Lee, Y., \& Gordon, R. H. (2005). Tax structure and economic growth. Journal of public economics, 89(5-6), 1027-1043.

Llacer, T., Miguel, F. J., Noguera, J. A., \& Tapia, E. (2013). An agent-based model of tax compliance: an application to the Spanish case. Advances in Complex Systems, 16(04n05), 1350007.

Mahangila, D. N., (2017). The Impact of Tax Compliance Costs on Tax Compliance Behaviour. Journal of Tax Administration 3(1), 2017.

Maina, A. W. (2017) The Effect of Consumption Taxes on Poverty and Income Inequality in Kenya. International Journal of Accounting and Taxation 5(2), 56-82.

Manhire, J. T. (2015). There is no spoon: reconsidering the tax compliance puzzle. Fla. Tax Rev., 17, 623.

McNichol, E. (2013), Strategies to Address the State Tax Volatility Problem. Eliminating the State Income Tax Not a Solution. Centre on budget and policy priorities

Musa, S. U., Saad, N., \& Ibrahim, I. (2017). Tax Structure Variables and Tax Compliance Behavior of Small Corporate Taxpayers in Nigeria: A Pilot Study. International Journal of Research in IT, Management and Engineering, ISSN 2249-1619, Impact Factor: 6.123, 7(1), 1-6.

Musgrave, R. A., \& Musgrave, P. B. (1973). Public Finance in Theory and Practice. New

Musgrave, R.A. (1969). Fiscal Systems. Yale University Press, New Haven.

Oboh, C. S., \& Adedeji, T. O. (2012). An Empirical Analysis of Tax Leakages and Economic Growth in Nigeria. Unpublished research work.

Odusola, A. F. (2006). Tax Policy Reforms in Nigeria. A Research work of United Nations University-World Institute for Development Economies Research, Research Paper, 03, 145 of Balkan and Near Eastern Studies, 13(2), 249-262.

Ogbonna, G. N., \& Ebimobowei, A. (2012). Petroleum income and Nigerian economy: Empirical evidence. Oman Chapter of Arabian Journal of Business and Management Review, 34(965), 1-27.

Ojong, C. M., Anthony, O., \& Arikpo, O. F. (2016). The impact of tax revenue on economic growth: Evidence from Nigeria. IOSR Journal of Economics and Finance (IOSR$J E F), 7(1), 32-38$.

Okafor, U. O. (2012). Analysis of the impact of fiscal policy measures on capital formation in Nigeria. Nigerian Journal of Management and Administration, 5(7), 34-56.

Okauru, I. O. (2011). Effective and Efficient Tax collection and Administration in Nigerian in the Three Tiers of Government. Retrieved From http://www.rmafc.gov.ng/2011 on $28 / 03 / 2017$

Okauru, I. O. (2012). Comprehensive tax history of Nigeria. Ibadan, Nigeria: Safari Books Ltd.

Okezie, A. I. (2012). Good governance and basic infrastructure development: its impact on growth and poverty reduction in Nigeria. International Journal of Advancement in Economic Science, 4(1). 
Okoh, J. I., Onykwelu, U. I., \& Iyidiobi, F. C. (2016). Effect of Petroleum Profit Tax on economic Growth in Nigeria. International Journal of Business and Management Review. 5(1), 47-53.

Okoli, M. N., Njoku, C. O., \& Kaka, G. N. (2014). Taxation and economic growth in Nigeria: A granger causality approach. International Journal of Research in Management, Science and Technology, 2(3), 64-80

Okonjo. I., (2013). Nigerian government hires tax consultants to increase revenue generation premium times Newspaper, November 27, 2013.

Okoye, C., \& Raymond, E. (2014). The impact of E-taxation on revenue generation in Enugu, Nigeria. International Journal of Advanced Research, 2(2), 449-458.

Okpe, I. I. (2003). Petroleum profit tax in Nigeria. Enugu: Joe Best Books.

Okwara, C. C., \& Amori, O. M. (2017). Impact of Tax Revenue on Economic Growth in Nigeria.

Okwori, R. \& Sule, M. (2016). Investigation of the impact of non-oil revenue on growth in Nigeria. International Journal of Science Research, 3(11), 45-58.

Oladipupo, A., \& Obazee, U. (2016). Tax Knowledge, Penalties and Tax Compliance in Small and Medium Scale Enterprises in Nigeria. Business, 8, 1-9.

Olaseyitan A. T., \& Sankay O. C. (2011). European Journal of Economics, Finance and Administrative Sciences\| ISSN 1450-2275 Issue 48 (2012). Euro Journals, Inc. 2012.

Oloidi, G. A., \& Oluwalana, L.O. (2014). Another approach to evaluating the productivity of value Added tax in Nigeria. Developing Country Studies, 4(15), 39-45.

Olopade, B. C., \& Olopade, D. (2010). The impact of government expenditure on economic growth and development in developing countries: Nigeria as a case study (No. 259600123). EcoMod.

Olugbenga, A. A., \& Ayeni-Agbaje A. R. (2015). Tax Structure and Economic Growth in Nigeria: A Disaggregated Empirical Evidence (1986-2012). Retrieved from https://www.semanticscholar.org/paper/Tax-Structure-and-Economic-Growth-inNigeria\%3A-A-Adaramola-AyeniAgbaje/d8736f126ca0a35d7fe1b5fbdfe3013459a5ee15

Omolehinwa, E. O., \& Naiyeju, J. K., (2015). Government Accounting in Nigeria: An IPSAS Approach. First Edition. Pumark Nigeria Ltd, Nigeria.

Onakoya, A. B., \& Afintinni, O. I. (2016). Taxation and Economic Growth in Nigeria. Asian Journal of Economic Modelling, 4(4), 199-210.

Onaolapo A. A., Fasina H.T., \& Adegbite T.A. (2013). The analysis of the effect of petroleum profit tax on Nigerian economy. Asian Journal of Humanities and Social Sciences, 1(1).

Onuoha, D. O., Ibe, A., Njoku, C. U., \& Onuoha, J. I. (2015). Analysis of The Gross Domestic Product (G.D.P) of Nigeria:1960-2012. West African Journal of Industrial \& Academic Research, 14(1).

Overton, M., Nukpezah, J. A., \& Ismayilov, O. (2017). Prepayments, late payments, and sales tax revenue volatility in Texas cities. Public Money \& Management, 37(7), 469-476.

Rodrik, D. (2008). One economics, many recipes: globalization, institutions, and economic growth. Princeton University Press.

Saheed, Z.S., Abarshi, J.A., \& Ejide, I.S., (2014). Impact of petroleum tax on economic growth in Nigeria (1970-2012). International Journal of Education and Research, 2(11), 297-307 
Schaufele, B. (2016). Taxes, Volatility, and Resources in Canadian Provinces. Canadian Public Policy, 42(4), 469-481.

Seegert, N. (2012). Optimal taxation with volatility: A theoretical and empirical decomposition. Job Market Paper, University of Michigan, 55.

Siyanbola, T. T., Adedeji, S. B., Adegbie, F. F., Rahman, M. M. (2017). Tax incentives and industrial/economic growth of sub-Saharan African States. Journal of advanced research in business and management studies, 7(2), 78-90

Sobel, R. H., \& Holcombe, R., (1996). Measuring the Growth and Variability of Tax Bases over the Business Cycle, National Tax Journal, 49, 535-552.

Success, M. J., Success, E. B., \& Ifurueze, M. S .K., (2012). Impact of petroleum profit tax on economic development of Nigeria. British Journal of Economics and Management Sciences, 5(2), 60-70.

Talvi, E., \& Vegh C. A. (2005). Tax base variability and procyclical fiscal policy in developing countries. Journal of Development Economics 78 (2005) 156-190. 